表 1

\begin{tabular}{|c|c|c|c|c|}
\hline 症 例 & 年 齢 & 性 & 疾 患 名 & 式 \\
\hline 1 & $12 \mathrm{y}$ & 우 & 大動脈炎症候群 & $\begin{array}{l}\text { 上行大動脈-右総䫫動脈 } \\
\text { 上行大動脈-左鎖骨下動脈 } \\
\text { 右椎骨動脈パッチ拡大術 }\end{array}$ \\
\hline 2 & $20 \mathrm{y}$ & 우 & $\begin{array}{l}\text { 左鎖骨下動脈狭窄 } \\
\text { (左鎖骨下動脈起始異常) }\end{array}$ & $\begin{array}{l}\text { 左総頸動脈-左鎖骨下動脈吻合術 } \\
\text { 動脈管索切離 }\end{array}$ \\
\hline 3 & $52 y$ & $\hat{o}$ & 右鎖骨下動脈閉塞症 & 右鎖骨下動脈血行再建術 \\
\hline
\end{tabular}

表 2

\begin{tabular}{|c|c|c|c|c|}
\hline 症例 & 遮断血管 & $\begin{array}{c}\text { 遮断時間 } \\
(\text { 分 })\end{array}$ & $\begin{array}{l}\text { Stump } \\
\text { pressure } \\
\text { (mmHg) }\end{array}$ & シャント法 \\
\hline 1 & 右総頸動脈 & 35 & $(-)$ & $(-)$ \\
\hline 2 & $\begin{array}{l}\text { 左総頸動脈 } \\
\text { 左鎖骨下動脈 }\end{array}$ & 42 & $60 / 51$ & $\begin{array}{c}\text { 外シャント } \\
(\text { 左大腿動脈- } \\
\text { 左総頸動脈 }\end{array}$ \\
\hline 3 & $\begin{array}{l}\text { 腕頭動脈 } \\
\text { 右総頸動脈 } \\
\text { 右鎖骨下動脈 }\end{array}$ & 65 & $56 / 48$ & $\left.\begin{array}{c}\text { 外シャント } \\
(\text { 上行大動脈- } \\
\text { 右総頸動脈 }\end{array}\right)$ \\
\hline
\end{tabular}

考案および結語

総頸動脈遮断時の脳虚血 monitor として, 最近大脳
皮質の指標である SEP が注目されている12. 今回われ われは SEP monitor 下総頸動脈を遮断し血行再建を 行った 3 症例について報告した. 総頸動脈遮断に際して はシャントの不要な症例もあるむのの, 一部には血流遮 断侕えられ症例があり 2)，シャントをするととは望 ましく, とくに銷骨下動脈屯遮断し同時に椎骨動脈の血 流を遮断する場合には重要と考えられた．また病変の程 度によってはシャント作成不能例があり, SEP monitor 下汇遮断を行えばより安全に手術しうるあのと考えられ た.

文 献 1) Symon, L. et al.: J. Neurosurg. 60: 269 1984。2) 菊池晴彦ほ加：脳神経 35：61，1983。

\title{
117 胸部大動脈瘤手術における補助手段の検討
}

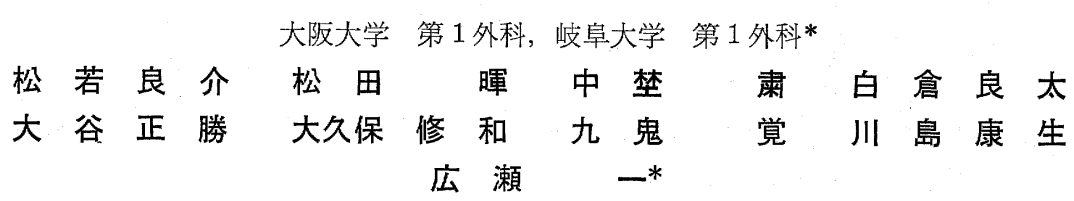

胸部大動脈瘤の手術成績は向上してきたが，いまだ種 種の問題がある，補助手段の手術成績に与える影響は大 きく，その臨床的検討は重要である. 今回最近の教室で 用いてきた補助手段から手術成績および合併症について 検討したので報告する.

\section{対象と方法}

1977 年 1 月から 1987 年 12 月の 11 年間飞胸部大 動脈瘤に対し待機手術を施行した 87 症例対象とし た. 性別は男性 62 例, 女性 25 例, 年齢は 15 79 歳, 平均 52 歳であった. 疾患の内訳は, 解離性大動脈瘤
40 例（I型 16 例， II 型 4 例，III型 15 例， I 型術後 の残存解離症例 5 例), 上行大動脈瘤は 15 例, 弓部大 動脈瘤 12 例, 下行大動脈瘤 18 例，求よびその他 2 例 である.用いたおむな補助手段の種類と症例数および 対象疾患を表 1 亿示した。 このうち脳分離体外循環法 （SCP 法）が 30 例 (34\%) と最屯多く, 対象疾患も弓 部敊よびその近傍に病変の及ぶ症例に広く用いられた。 現在行っている SCP 法の方法は, 超低体温法を併用し 脳灌流は 2 基のポンプで別々に腕頭動脈, 左総頸動脈へ 3:2 の割合で送血している. 動脈圧は右上，下肢のほ かに両側浅側頭動脈圧をモニターし，原則としててれを 
表 1 おむな補助手段の種類と症例数および対象疾患（1977/1～1988/12）

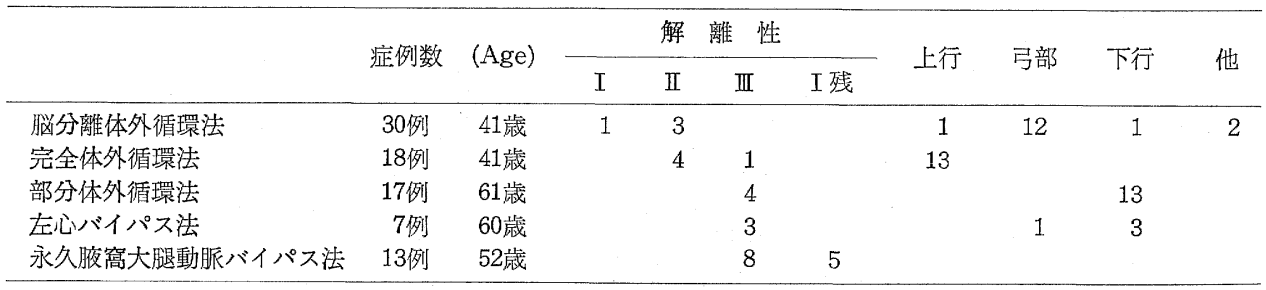

1988/2 Osaka Univ.

$50 \mathrm{mmHg}$ 以上に保つように灌流している。ささらに 1982 年以降は真性動脈瘤の症例において末梢側遮断に大動脈 閉塞用バルーンカテーテルを併用し手術操作の簡易化を 罒っている1). AAE を中心とした上行大動脈に限局す る大動脈瘤には，大腿動脈送血，上下大静脈脱血の完全 体外循環法（TCPB 法）を用いた，下行大動脈領域の 病変には左房脱血による左心バイパス法と大腿動静脈を 用いた部分体外循環法（F-F 法）を用いたが，現在は原 則として F-F 法を用いる方針をとっている， III型解離 およびI型残存解離症例に対しては，1980 年より原則 として瘤縫縮十永久腋窩大腿動脈バイパス (Ax-F 法) 術を行っている．乙の場合は術式の一部であある永久腋 窩大動脈バイパス術が大動脈遮断中の補助手段にもなっ ている．方法は通常の axillo-unifemoral bypass と同 様人工血管は径 $10 \mathrm{~mm}$ の knitted Dacron graft を用 いた.

\section{結果}

全体としての手術成績は病院死 1 例を含めた早期死亡 は 12 例 $(14 \%)$ で, 1982 年までを前期, 1983 年以降 を後期とすると死亡率は前期 19\% から後期 $10 \%$ へ 改善した，死し例を除いた耐術 75 例におけるおすな合 併症は脳神経障害 4 例, 腎不全 2 例, 出血 2 例, 肺炎 1 例であった．とのうち脸障害以外の合併症は後遺症を残 さず治癒した（表 2 ).

以下現在用いている補助手段別の成績について述へ る.

$\mathrm{SCP}$ 法 (30 例) : 分離体外時間は $122 \pm 63$ 分 (mean $\pm \mathrm{SD})$, 大動脈遮断時間 $122 \pm 63$ 分, 下半身の灌流量は $1.2 \pm 0.3 \mathrm{l} / \mathrm{min} / \mathrm{m}^{2}$, 脳灌流量は $0.4 \pm 0.1 \mathrm{~m}^{2}$ であった。 死亡は 2 例 $(7 \%$ ）で，プロタミンに対するアナフィラ キシーショックで台上死した 1 例と, 抗生剤による術後 紅皮症にて死亡した 1 例である．耐術例での合併症は脳 障害，腎不全各 1 例であった，脳障害の例は右脳梗塞に よる左半身マヒが後遺症として残存した.
表 2

手術成績（1）（1977/1 1987/12)

\begin{tabular}{|c|c|c|c|}
\hline \multicolumn{4}{|c|}{ 術後早期死亡：12/87 例（14\%）(手術死+病院死) } \\
\hline \multirow{2}{*}{ 死 } & \multirow{2}{*}{ 例 数 } & 前 期 & 後 期 \\
\hline & & $\sim 1982$ & $1983 \sim$ \\
\hline 出血 & 4 & 4 & \\
\hline sepsis & 2 & 2 & \\
\hline LOS & 1 & & 1 \\
\hline 腎不全 & 1 & & 1 \\
\hline 偽腔送血 & 1 & 1 & \\
\hline プロタミンショック & 1 & & 1 \\
\hline 術後紅皮症 & 1 & & 1 \\
\hline 突然死 & 1 & & 1 \\
\hline & 12 & $\begin{array}{c}7 / 37 \\
(19 \%)\end{array}$ & $\begin{array}{c}5 / 50 \\
(10 \%)\end{array}$ \\
\hline
\end{tabular}

手術成績（2）（1977/1～1987/12）

\begin{tabular}{|c|c|c|c|}
\hline \multirow{2}{*}{\multicolumn{2}{|c|}{ 而術 75 例におけるおむな合併症 }} & \multirow{2}{*}{$\begin{array}{l}\text { 前 期 } \\
\sim 1982\end{array}$} & \multirow{2}{*}{$\frac{\text { 後 期 }}{\text { 1983 }}$} \\
\hline & & & \\
\hline 脳神経障害 & $4(5 \%)$ & 1 & 3 \\
\hline 腎不全 & $2(3 \%)$ & 1 & 1 \\
\hline 出血 & 2 & 1 & 1 \\
\hline 肺炎 & 1 & & 1 \\
\hline & $9(12 \%)$ & $\begin{array}{c}3 / 30 \\
(10 \%)\end{array}$ & $\begin{array}{c}6 / 45 \\
(13 \%)\end{array}$ \\
\hline
\end{tabular}

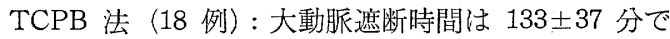
あった１例（6\%）をLOSにて失った。耐術例では 督不全を 1 例に認めた以外は合併症は認めなかった。

$\mathrm{Ax} \cdot \mathrm{F}$ 法 (13 例) : 死亡は 3 例 $(23 \%)$ で死因は腎不 全, sepsis，原因不明の突然死 (12 POD) であった．耐 術例での合併症は出血 1 例であった.

$\mathrm{F}-\mathrm{F}$ 法 (17 例) : 体外循環時間は $178 \pm 78$ 分, 下半 身灌流量は $1.1 \pm 0.1 \mathrm{l} / \mathrm{min} / \mathrm{m}^{2}$ であった．死亡は前期の 本法施行例 5 例のうち 4 例で発生し, 死因は出血 2 例, sepsis，偽腔送血による心停止であった，後期の 12 例で は死亡はなかった，耐術例での合併症は脳障害 3 例，呼 吸不全 1 例でありすべて後期に発生した，脳障害例では 
表 3 胸部大動脈瘤手術におけるおすな補助手段の成績のまとめ (1977/1 1987/12)

\begin{tabular}{|c|c|c|c|c|c|c|}
\hline & \multicolumn{2}{|c|}{ 前期（～1982） } & \multicolumn{2}{|c|}{ 後期 (1983 ) } & \multirow{2}{*}{$\begin{array}{r}\text { 総 } \\
\text { morta }\end{array}$} & \multirow{2}{*}{$\frac{\text { 計 }}{\text { morbi }}$} \\
\hline & morta & morbi & morta & morbi & & \\
\hline 脳分離体外循環 & $0 \%$ & $22 \%$ & $9 \%$ & $0 \%$ & $6 \%$ & $6 \%$ \\
\hline 完全体外循環 & $0 \%$ & $9 \%$ & $14 \%$ & $0 \%$ & $6 \%$ & $6 \%$ \\
\hline 部分体外循環 & $80 \%$ & $0 \%$ & $0 \%$ & $31 \%$ & $23 \%$ & $23 \%$ \\
\hline 永久腋窩大腿動脈バイパス & $33 \%$ & $0 \%$ & $20 \%$ & $10 \%$ & $23 \%$ & $8 \%$ \\
\hline
\end{tabular}

四肢麻痺, 左半身麻㽻（ 2 例）の後遺症が認められた。

\section{考察およびまとめ}

胸部大動脈瘤に対する補助手段として現在用いている 主な補助手段は, TCPB 法, SCP 法, F-F 法, Ax-F 法の 4 種類である.それぞれの方法は疾患の部位，種 類, さらには術式により選択されるあのであり, 同一レ ベルでの比較は困難であるが, それぞれのもつ利点, 問 題点を示した.

TCPB 法, Ax-F 法施行例では補助手段法と関連があ ると考えられる死亡および合併症の発生はなかった. し たがっててれら二つの方法は補助手段としては，それぞ れ主として上行大動脈瘤および DB-III+I 型残存解離 を対象とする場合とくに問題はないと思われる.

従来，弓部大動脈瘤手術では手技の改良等によりその 成績は向上してきたが mortality, morbidity とむに, 必ずしあ良好ではない22. しかし，今回のわれわれの 30 例の弓部およびその近傍の動脈瘤に対する SCP 法施行 例では死亡は 2 例 $(6 \%)$ と低く, 脳合併症も 1 例のみ であった. SCP 法については至適脳灌流量等の点でい まだ問題が残されているが, 適切な脳灌流モニターと灌 流圧を $50 \mathrm{mmHg}$ 前後に維持する管理のもとに行えば 有用かつ安全な補助手段であるといえる ${ }^{32}$.

下行大動脈領域の病変に詨する F-F 法施行例では, mortality は後期で前期に比し改善したものの脳障害は 3 例発生し，いずれも後遺症が残存した．乙の F-F 法 3 例中 2 例では, 血圧の変動, 大動脈遮断部からの遊離 血栓が脳障害の原因である可能性が考えられた．以後の 例では血圧を厳重に管理し，また遮断解除時には血栓の 頭部への逆行性塞栓を防止するために上肢血圧が下肢血 圧より高くなるようにコントロールした，ての結果最近 の 5 例では脳合併症の発生をみていない.

対象例の一部では左心バイパス法も用いられたが，脱 血が不十分になることが多い等の理由から現在ではその 使用は中断している.

以上まとめると（表 3 )，

1) 弓部拉よびその近傍病変を対象に脸分離体外循環 を応用し, mortality, morbidityともに満足しうる成績 を得た。

2) 下行大動脈領域の病変における部分体外循環法 は，前期では主として出血による高い mortalityを，後 期は脳合併症による高い mortality を伴った.

3） DB-III型 8 例, I 型残存解離 5 例の計 13 例に対 して永久腋窩大腿動脈バイパス術を併用し, 術中補助手 段としては問題がなかった。

文 献 1) Hirose, H. et al.: Ann. Thorac. Surg. 39: 538, 1985. 2) Livesay, J. J. et al.: Ann. Thorac. Surg. 36: 19，1983. 3) 広瀬一ほ加：日胸外会誌 34:673, 1986. 